\title{
THE SLING EFFECT: CROATIA AND SEE AFTER THE FALL OF THE BERLIN WALL
}

\section{Šonje, V.}

Velimir Šonje / Founder of ARHIVANALITIKA, EKONOMSKI LAB, Ivana Kukuljevića 32, 10000 Zagreb, Croatia.Email: vsonje@arhivanalitika.hr

\begin{abstract}
The concentration of real convergence in a short period before the Great Recession (20012008) is a characteristic shared by many countries, but it was particularly pronounced in Croatia, Serbia, Bosnia and Herzegovina and Bulgaria. Bulgaria managed to converge after the Great Recession, but convergence in other mentioned countries was meagre; Slovenia even diverged since 2010. Direct effects of post-Yugoslav wars belong to the past, but indirect effects may have had more persistent effects: a lost decade of the '90s led to weak institutional development and the creation of the local form of state capitalism, which provides weak fundamentals for economic growth. Monetary policy and exchange rate regimes in the region are mostly centred around stable exchange rates and strive for the introduction of the Euro (Bulgaria and Croatia joined the ERM II in 2020). However, the impact of exchange rate regimes on long-run economic growth is neutral. Preference for credibility building monetary regimes is a legacy of the past. Financial predictability served as a shock absorber and a substitute for good institutions in order to attract inflows of international capital, which flooded ex-communist countries after the emerging markets crisis in the late '90s. However, when the wave of capital inflows stopped in the Great Recession, more fundamental growth factors emerged, explaining the slow convergence of the majority of SEE countries in the second decade of the 21 st century.
\end{abstract}

Keywords: transition; convergence; institutions; monetary policy; exchange rate regimes JEL Classification: P16, P24, P30, P37

\section{Introduction}

Thirty years after the fall of the Berlin Wall, Croatia and other countries which gained independence after the break-up of former Yugoslavia failed to achieve sustainable longterm convergence towards EU standards of living. Periods of relatively rapid income convergence did occur, for example, in the first years of the 21 st century, but did not turn into sustainable long-run convergence. Convergence paths in the Baltics and the CEE were long-lasting compared to paths recorded in countries of former Yugoslavia. 
The first potential explanation is the post-Yugoslav wars. Wars affected Croatia (19911995), Bosnia and Herzegovina (BiH) (1992-1995), Kosovo (1998-1999 after 18 years of latent atrocities) and to a lesser extent North Macedonia (2001). Wars also heavily affected Serbia. The regime led by Slobodan Milošević started a decade of atrocities in the '90s due to Serbia's attempt to keep control over most of the territory of former Yugoslavia irrespective of the republic's borders.

Besides direct impacts, wars had indirect effects through slow democratic development and shaping of (weaker) political and economic institutions compared to Baltics and core CEE countries. As a consequence, the late EU accession process also had a negative impact on economic growth. Lag in the EU accession had a direct impact through lack of trade integration. Indirect impact manifested through lack of pressures on institutional reforms.

The late accession process should be understood as a proximate cause of slow convergence. It was fundamentally caused by historical and institutional factors with longlasting influence. The chaos of the ' 90 s led to the establishment of new states, para-states and protectorates point at internal divisions within Bosnia and Herzegovina as para states and $\mathrm{BiH}$ itself as a protectorate, as international envoy plays a constitutional role in its political life even today (Bićanić \& Franičević, 2003). The only exception was the most developed former Yugoslav republic (and until recently, the most developed postcommunist country $)^{1}$, Slovenia, which was considered outside the zone of influence by Milošević's regime. Slovenia joined the EU in the first wave of EU accession in 2004. Croatia joined nine years later, in July 2013, while other countries in the region obtained candidate status only (North Macedonia, Albania, Serbia, Montenegro), or still are only hoping to get it (Bosnia and Herzegovina and Kosovo). ${ }^{2}$

All peripheral SEE economies are small and open. Their size in terms of population ranges from below 1 million (Montenegro: 620 thousand) and around 2 million (Slovenia, Kosovo), 3 to 4 million (Albania, Bosnia and Herzegovina, Croatia), to around 7 million (Serbia, Bulgaria) and 19 million (Romania).

SEE countries trade more with larger EU economies than with each other. Productivity developments are dependent on imports of capital and technology. Transfers from the diaspora, which is largely located in developed EU member states, play an important role in financing chronic trade deficits (private transfers range as high as $8 \%$ of GDP in Bosnia and Herzegovina, twice higher than in, e.g. Croatia). Continuous outgoing migration and loss of populations (except in Slovenia and Montenegro, where the population is stable) is a

\footnotetext{
12009 was the first year when Czechia recorded higher GDP per capita than Slovenia according to Eurostat's purchasing power standard.

2 North Macedonia applied for membership in 2004, gained candidate status in 2005, but was blocked by Greece due to dispute over country's name until Macedonia changed its name into North Macedonia in 2019; EU negotiations are currently going on with Montenegro, Serbia and Albania, which gained candidate status in 2010, 2012 and 2014 respectively; Turkey has official candidate status, but president Erdogan made EU initiatives irrelevant and perspectives bleak; Bosnia and Herzegovina (BiH) applied for membership in 2016 but currently floats in a political limbo due to internal political tensions (EU envoy still participates in political decision making in BiH), hoping to get the candidate status soon; Kosovo, formerly part of Serbia and mostly populated by Albanians declared independence from Serbia in 2008, but is still only partly recognized (although member of most international organisations) by 22 of 27 EU member countries (including Slovenia and Croatia); Serbia and Bosnia and Herzegovina do not recognize Kosovo's independence, but country has the status of potential EU candidate which may unfreeze only after Serbia and Kosovo reach final agreement on mutual relations.
} 


\section{DISCUSSION}

historical constant in the region: emigration limits long-run socio-economic growth as young and entrepreneurial leave their home countries. ${ }^{3}$

With such weak fundamentals, countercyclical monetary and fiscal policies have had a limited role in the region. Fiscal policy is constrained by weak and corrupted public sectors, which hardly earn credibility in international financial markets, though presently low-interest rates and hunger for yields ease market access for all countries in the region. Croatia and Bulgaria enjoy investment grade of sovereign credit ratings, but other sovereigns have junk status. This resulted in shallow markets for public debt instruments and a lack of financial intermediaries, especially non-banks and capital markets. Monetary policy is constrained by the very nature of small and open economies: currency depreciation and associated expectations threaten rapid pass-through onto domestic prices and interest rates. Autonomous monetary policy is also limited by the extremely important role of private transfers (across the region) and tourism (Croatia and Montenegro): this led to euroisation of local economies on top of widely circulating foreign exchange, which is a legacy of the socialist period. FX deposits are the instrument of the main savings since the period of high inflation in the '70s and '80s, which still resonates in the collective memories of people in the Balkans.

Weak economic and institutional fundamentals made macroeconomic stabilisation policy subservient to a need to have stable nominal exchange rates. They served to anchor volatile expectations, alleviating propagation of negative shocks (prevention of negative balance sheet effects and rapid pass-through) and attraction of capital inflows. Serbia, which used an inflation targeting regime with a more flexible exchange rate after 2000, managed to promote the export orientation of its economy after the Great Recession of $2008 / 09$. However, this structural transformation was not reflected in faster convergence.

With standard macroeconomic stabilisation tools largely absent, and with weak fundamentals driving slow growth trajectories in countries that once constituted Yugoslavia's federation, one key question begs for an answer: what if the EU integration was faster, i.e. what if there were no atrocities if former Yugoslavia could split in a peaceful way like Czechoslovakia, or at least in a less hostile way like the USSR in the early 1990s?

One can speculate that there would still be factors at play in the post-communist era, causing most countries of former Yugoslavia to lag in terms of convergence behind Baltic 3 and CEE 4 (Poland, Czechia, Slovakia, Hungary). There are two such potential anchors with long-term duration: (1) political and economic liberalisation coupled with EU integration re-established old continental economic geography; history favoured Central Europe over Balkans due to faster integration and proximity of more developed regions of Germany, Austria and Northern Italy (this does not apply to Slovenia which was trade-integrated in socialist times already); and (2) the sling effect, meaning that more centralised, closer to command-type socialist economies (Baltic 3 and CEE 4 - Poland, Czechia, Slovakia and Hungary) had stronger incentives and more political energy for initial political and economic

\footnotetext{
${ }^{3}$ According to Eurostat's estimates, combined population of Croatia, BiH, Kosovo, Montenegro, Serbia, North Macedonia and Albania declined from 23.3 to 21.8 million i.e. around 9\% in about a decade between 2009 and 2020. Croatia recorded decline from 4.3 to 4.06 million, that is $-6 \%$.
} 
reforms after the collapse of communism compared to societies with the more decentralised type of socialist institutions (including economic ones), which existed in former Yugoslavia.

The sling effect has many facets: the tension of the sling's reform catapult after the fall of the Berlin Wall depended on the education level, structure and beliefs of the transition elite. By the same token, the sling effect is more than an explanation limited to events in the '90s only. If exists, the sling effect may have a wider relevance outside the SEE, because three decades after the fall of the Berlin Wall, as this crucial historic event gradually becomes the forgotten chapter in the books on history, new power structures consolidate around new institutions which do not necessarily reflect the rules and spirit of liberal democracy. New incentive structures and political energy for change may take unforeseen directions and drive the CEE, not only the SEE, away from liberal democracy and open market economy. This thesis is discussed in the concluding section of this paper, which uses institutional analysis to explain post-communist developments in the region with particular emphasis on exchange rate regimes.

The first two sections present an examination of fundamental factors beyond post-Yugoslav wars. These factors played a role in shaping the post-communist era in SEE - new European geography and the sling effect of reforms. The third section provides a detailed insight into monetary and exchange rate regimes in the region, showing their endogeneity (institutional dependence) in the long run. The fourth section concludes.

\section{Three stylised facts about the SEE: convergence, institutions and monetary policy}

Baltic countries (Baltic 3) and Romania are the forerunners of the post-communist convergence process since 1995. They are followed by CEE 4: Poland, Czechia, Slovakia and Hungary (Figure 1). Croatia lags behind CEE 4 and other countries in SEE, except Montenegro, lag behind Croatia. Given beta-convergence (growth being dependent upon initial level of development), the place of Montenegro in this group of rapidly converging post-communist countries is not surprising: its dip in the '90s and potential for catch-up was extreme because the smallest SEE country converged due to strong capital inflows related to property business and tourism. ${ }^{4}$

\footnotetext{
${ }^{4}$ Most of it happened in a short period between 2001 and 2008 when plenty of Russian capital flew to Montenegro which has a relatively long coast in southern Adriatic region. Only very small and specialized economies can have such simple convergence stories driven by idiosyncratic sectoral factors. All other economies in the region are too large and complex to have such a simple explanation of convergence.
} 
Figure 1 | Main features of convergence 1995-2019 as measured by change in GDP per capita at purchasing power standard as $\%$ of Austrian level ${ }^{5}$

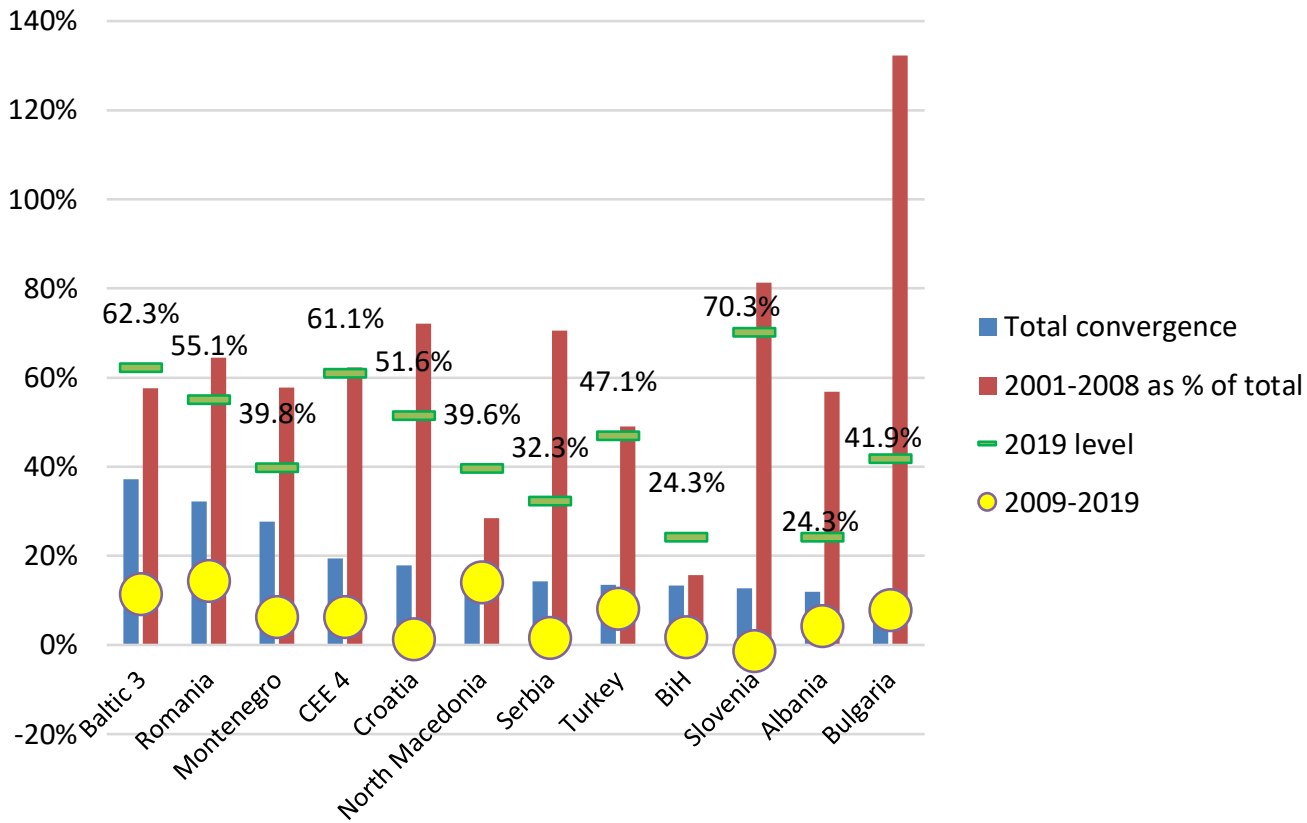

Source: Eurostat, Maddison Project Database (2020)

The concentration of real convergence in a short period before the Great Recession (20012008) is a characteristic shared by many countries, but it was particularly pronounced in Croatia, Serbia, BiH, Slovenia and Bulgaria. Circles in Figure 1 show that Bulgaria managed to converge after the Great Recession, but this was not the case, at least not to a significant extent, in Slovenia, $\mathrm{BiH}$, Serbia and Croatia (see how their circles sit on the $\mathrm{x}$ axis). ${ }^{6}$ We shall explore this fact below.

It is not surprising that Slovenia's total convergence was among the slowest since 1995. Slovenia was already positioned as the most developed post-communist country in 1995, with GDP per capita in real terms at $58 \%$ of the Austrian level (see also Table A1 in the

\footnotetext{
${ }^{5}$ Austria was chosen as a benchmark for three purposes. First, it is a historic benchmark since most CEE and SEE countries were parts of Austro-Hungarian Empire until 1918 or were influenced by it. Second, Austria is important trading partner for countries in the region. Third, usual measurement vs. EU-27 average conceals many aspects of convergence (e.g. convergence can arise from relative decline of countries like Italy, Greece or U.K., which does not reflect success of post-communist countries. Also, own data influence EU averages. Furthermore, notice (case of Bulgaria) that convergence 2001-2008 as a \% of total convergence can be higher than 100\%. Bulgaria also converged from 2009 to 2019. It is because of Bulgaria's rapid divergence in the chaotic 90's (-10.8 pp) - see Table A1 in the Appendix.

${ }^{6}$ CEE 4 experience was not uniform during the decade from 2009 to 2019. as Slovakia diverged from EU average by 2 percentage points. This result, which is related to Eurostat's purchasing power standard calculation is a puzzle, because Slovakia managed to grow at $3 \%$ on average in the second decade of the $21^{\text {st }}$ century. There is a substantial difference between change in GDP deflator and change in relative price level used for purchasing power standard calculations. This topic is beyond the scope of this paper.
} 
Appendix). On the other hand, the total convergence of Albania, BiH, Serbia and North Macedonia since 1995 appears to be slower than expected. It was reasonable to expect faster convergence of SEE countries compared to Baltics, CEE 4 and Croatia. However, it did not happen. North Macedonia is a notable exception besides Montenegro, as this country managed to achieve convergence comparable to Romania since 2009.

Stylised fact no. 1: Convergence in Croatia and the SEE was slower than expected and concentrated in the period before the Great Recession (2001-2008), with post-Great Recession convergence being very slow in Albania, Slovenia, BiH, Croatia and Serbia.

The vast literature on institutions and growth offers potential explanations for divergent paths of countries in CEE and SEE after the fall of communism. The economic literature is not conclusive about the direction of causation. North-Acemoglu tradition (Acemoglu et al., 2005; North et al., 2009) emphasises direct causation, which runs from inclusive (depersonalised, open-access) institutions to growth. Other strands of institutional literature emphasise the proximate role of human capital as being the main driver of both institutional change and growth (e.g. Glaeser et al., 2004). Other authors tend to view the nexus of institutions, human capital and growth as a snapshot from a complex system where causations move in different directions (key factors reinforcing each other).

Regardless of the causality problem, the correlation between institutional quality and convergence in Central, Eastern and South-Eastern Europe is obvious. Data in Figure 2 and Table $\mathrm{A} 2$ in the Appendix show that:

a) Baltic 3 made consistent long-term progress in developing democratic institutions (regulating voice and accountability, the rule of law and control of corruption), in some areas even reaching institutional quality of Austria (e.g. corruption control in Estonia is comparable to Austria);

b) CEE 5 (CEE 4 + Slovenia) made rapid institutional improvements in the first few years of post-communist transition, which was followed by the long period of institutional fatigue marked by institutional stagnation or regression. For example, Slovenia, Czechia, Hungary and Poland never came back to the 1995 level of quality of institutions regulating voice and accountability and control of corruption; the result is the same regarding the rule of law in Poland and Hungary;

c) SEE countries were in a dip of the black hole of institutional development by 1995 (confirming the importance of war hypothesis), but their paths diverged afterwards; Croatia improved its democratic institutions (which is in line with the hypothesis about the importance of EU accession), while other countries in the region displayed either very slow institutional evolution, or stagnation and regression at the low level of institutional development. 
Figure 2 | Institutions and convergence: Baltics, CEE and SEE

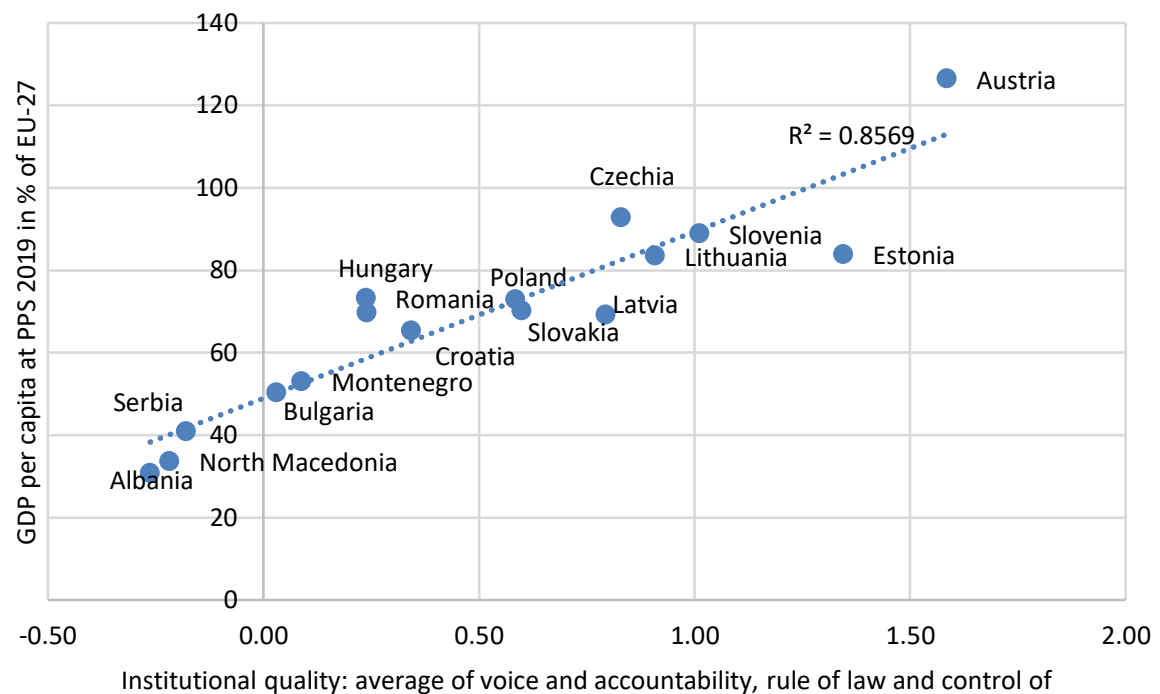

coruption, 2019

Methodological note: The Figure omits Turkey due to its different history and includes Austria (dot in the far north-east of the diagram). For a full data set, see Table A2 in the Appendix. The indicator on the $x$-axis is a simple average of values of institutional quality for voice and accountability, the rule of law and control of corruption which constitutes the World Bank's WGI. ${ }^{7}$

Source: Worldwide Governance Indicators (WGI), Eurostat.

Stylised fact no. 2: With a notable exception of Baltic states (Estonia and Lithuania especially), which exhibited a capacity for continuous institutional improvement towards high levels of institutional development, institutions in CEE and SEE countries changed discretely; the change was pronounced in the first half of the '90s in CEE 5 and later on in Croatia under the pressure of (late) EU accession. In general, SEE remained laggard in terms of the development of inclusive, open institutions.

How do monetary and exchange rate regimes fit into the story about institutions and convergence? The collapse of socialism and the history of high inflation, which carried over from the ' 80 s, were amplified by price liberalisation in the early ' 90 s. Such evolution had hurt the post-communist recovery and forced former communist countries to prioritise monetary reforms in the early stage of transition. Smaller countries preferred stable exchange rate regimes, which brought credibility and helped coordinate expectations. This logic was present outside the SEE as well: Estonia introduced a currency board in 1992 followed by Lithuania in 1994; currency boards were kept until the introduction of Euro in

\footnotetext{
7 Other WGI indicators (political stability and absence of violence, government effectiveness and regulatory quality) were not used in this calculation as their relationship to overall democratic development is loose. Authoritarian societies (e.g. Singapore) may rank very high across these dimensions and be very low on the democratic scale at the same time.
} 
Estonia and Lithuania in 2011 and 2015, respectively; development in Latvia was similarly based on the fixed exchange rate regime which ended with the introduction of euro in 2014. Croatia curbed down high inflation by heterodox stabilisation program during the war in 1993 and navigated through a narrow (unannounced) dirty peg nominal exchange rate interval of $+/-4.3 \%$ vis a vis DEM and EUR until entry to the European exchange rate mechanism in July 2020. Post-communist financial turmoil lasted longer in Bosnia and Hercegovina, and Bulgaria. Both countries managed to stabilise finances by the introduction of currency boards in 1997 (Bulgaria also joined ERM II in July 2020, which BiH could not do because it is not a member state yet). Officials in Kosovo and Montenegro knew that the EU entry is a distant moving target, so they skipped their own currencies and opted for the one-sided introduction of Euro managed by their own central banks outside the Eurosystem (since 2002). This is sometimes vaguely called unofficial euroisation, but it should be viewed as a natural extension of earlier unofficial (spontaneous) substitution of former and only formally domestic Yugoslav dinar by German mark during the war and institutional chaos of the '90s. Slovenia was a forerunner of euro introduction in 2007 after it curbed down high inflation in a more gradual manner in the '90s. However, as inflation remained moderate, Slovenia followed a crawling peg (gradual depreciation of domestic currency at moderate rates) in order to prevent chronic moderate inflation from appreciating national currency in real terms before entry to the Euro Area. After the chaotic '90s, Serbia and Romania leaned towards inflation targeting, similar to Czechia, Poland and Hungary.

Perhaps a claim that there are close links between general institutional developments and choice of monetary and exchange rate regimes is too far-fetched, although there is a long tradition of this view in economic literature (e.g. Leblang, 1999). Nevertheless, recent monetary history in SEE shows that three factors - small size (openness) of the economy, history of high inflation and weak institutions - promoted the emergence of stable nominal exchange rate regimes in search for predictability and control of volatile inflation expectations. In this sense, development in the Baltic states was not very different from developments in SEE: chaotic dissolution of the USSR produced similar trade and financial shocks like in SEE. As a consequence, post-communist governments were in a desperate search for financial stability. Twenty-five to thirty years later, we may conclude that monetary arrangements have been sustainable as no country from the Baltic to the Black Sea experienced a currency crisis and regime break-up under speculative attack.

Serbia appears to be an outlier in this respect. After the hyperinflationary chaos of the ' 90 s, post-Milošević ${ }^{8}$ flexible exchange rate within an inflation targeting regime may have helped export orientation: Serbia increased its ratio of total exports to GDP from $25 \%$ to $50 \%$ from 2007 to 2019. However, as indicated earlier, higher exports to GDP ratio did not contribute to real convergence after the Great Recession when Serbian income per capita in real terms did not converge towards the Austrian level (see Figure 1 and Table A1 in the Appendix). Weak institutions may have prevented widespread sharing of gains from the revival of international trade.

Stylised fact no. 3: Small and open economies in SEE tend towards stable exchange rate regimes and introduction of Euro. Pegs have been sustainable.

8 Milošević's reign was overthrown during mass protests in October 2000 which soon led to his extradition to the International Hague Tribunal in June 2001. 


\section{In search for deep explanations: the sling hypothesis}

Post-Yugoslav wars, the collapse of trade, high inflation and chaotic institutional developments during war times provide an attractive first-hand explanation of different transition trajectories in SEE compared to Baltics and the CEE. Metaphorically, people have been fighting and spending months in cellars at places like Vukovar, Sarajevo and Dubrovnik, while VW acquisition of stakes in Skoda symbolised the establishment of new patterns of investment and trade in open New Europe. Intuitively, such a difference should matter for a long time.

However, it is not easy to explain how war effects could persist for 15-20 years and explain slow convergence after 2009, when Croatia, Serbia, BiH and Slovenia converged very slowly or did not converge at all (Slovenia diverged). In this respect, slow convergence in SEE is a puzzle.

Another comparison with Baltic 3 comes to mind. Life was not much easier in the Baltics in the early '90s. The chaotic process of the USSR's dissolution did not cost as many lives as post-Yugoslav wars, but uncertainty, institutional chaos and collapse of trade were of similar historical proportions like in SEE. Also, the economies of new states were too small to produce internal economic dynamics. The strength of the initial shock was reflected in a deep dip of output in Baltic economies at that time, which was comparable to output collapse in countries successors of former Yugoslavia (see Table A1 in the Appendix). Therefore, it is not that straightforward to use war and war-related problems in SEE as a predominant direct explanation of (relatively) slow convergence after 2009, as Baltic 3 made it in a spectacular way.

Yet, there are three additional factors of slow institutional transformation in SEE which may explain the lack of drivers for change that were present in CEE and Baltics but absent in SEE after 1989:

a) The proximity of EU promise. Institutional transformation in CEE and Baltics was rapid in the '90s due to the promise of catch-up in the first wave of EU enlargement; this motivation was absent in SEE where new political elites were aware that the EU is a distant moving target which cannot help them to get reelected (this represents the indirect impact of wars).

b) Escape from the Eastern threat. Baltic 3 were additionally motivated for reforms by escaping from the zone of Russia's influence as fast as possible (to some extent, this motive was present in CEE 4, which shared historical frustration related to Soviet influence); this motivation was absent in the countries of former Yugoslavia which spent socialist times after 1948 outside the zone of Soviet influence. We will discuss the importance of this fact in detail further in the text. Notice that this hypothesis has nothing to do with the war; it would manifest anyway, even in the case of the peaceful dissolution of former Yugoslavia.

C) New people and new ideas. The rotation of elites was more pronounced in the Baltics and the CEE compared to SEE, even in countries that did not follow direct lustration policy. In SEE, communists turned nationalists ran the historical process 
and national homogenisation at wartime led to compromises between old and new elites (e.g. Croatia, Bosnia and Herzegovina, Serbia, Slovenia); this hypothesis also counts among indirect impacts of war.

The remainder of this section offers explanations for factors (b) and (c) as (a) is selfevident.

Outside the economic realm, transition elites in the CEE and the Baltics were initially inspired by ideas of liberal democracy and freedom, in many cases led by intellectuals and leaders who shared sympathies for the market economy. It bore the promise of old glory as a generation of reformers who helped the Berlin Wall to fall shared memories of their grandfathers: Baltic states, Czechoslovakia, Poland and Hungary were not lagging so far behind Austria and Germany in terms of economic development in the '30s of the 20th century as they did in the '80s.

Deep history is also related to the educational structure of societies: average share of people with less than primary, primary and lower secondary education in working-age population was around 23\% in Baltic 3 and CEE 4 around the year of 2000. The first data available in Eurostat's database stand at 31.2\% for Croatia (2002), 30.6\% for Slovenia (1999), 29.3\% for Serbia (2010) and 44\% for North Macedonia (2006). General education level is known to be an important factor for both institutional and economic development (Glaeser et al., 2004).

In CEE 4 and Baltics 3 there were no doubts among members of the new elite that the era of Soviet influence and attempts to impose a command economy brought relative economic decline (data support the thesis - see Table A1 in the Appendix). Prevailing opinions were different in former Yugoslavia. In the late '80s and early '90s, there was no clear economic ideology except ideas rooted in deeper desires for national independence and/or throwing the old communist elite out from the power throne. There were no collective memories or intellectual tradition that could provide a strong ground for belief in liberal democracy, market economy and capitalism. There was a wide understanding among the new elites in SEE that something went wrong with the economy of former Yugoslavia around 1980, and everybody was aware that the '80s brought high inflation and economic decline, which added fuel to political fires in a tension-burdened federation. However, economic developments from the early '50s until the late '70s (see Table A1 in the Appendix and Bićanić et al., 2016) were seen in a more positive light, even by anti-communists.

Moreover, war was a fertile ground for the re-establishment of new forms of authoritarianism. Many political techniques, which are nowadays interpreted as new forms of illiberal authoritarianism or despotism (Keane, 2020) (e.g. judicial reforms in Poland and control of media, courts and civil society in Orban's Hungary), were consistently applied in SEE countries in the '90s. Orban's "invention" of George Soros as a symbolic state enemy is just a re-invention of Croatian President Franjo Tuđman's rhetoric in the '90s.

Most anti-communists in former Yugoslavia were socialists, and many of them excommunists who opposed the Yugoslav communist regime on the grounds of national liberation and independence. First presidents of Slovenia (Milan Kučan), Croatia (Franjo Tuđman), Montenegro (Momir Bulatović), Serbia (Slobodan Milošević) and North Macedonia (Kiro Gligorov) were high officials during communism. Tuđman was the only one among them who turned against the regime in the '60s and was imprisoned two times due 


\section{DISCUSSION}

to advocacy of Croatian independence. The first president of Bosnia and Herzegovina (Alija Izetbegović) was a religious leader who saw Islam as the base for the national liberation of Bosnian Muslims within the broader context of Islam civilisation. He was also imprisoned by communists in the '80s. No liberal party, individual or political alliance came close to power in the SEE in the '90s.

In general, views on the economy were of the second order of importance, except the high inflation problem, which will be addressed in more details below in the text.

Confusion about sources of economic malaise and potential remedies can be understood in light of Yugoslav economic history. After the split between Tito and Stalin in 1948, former Yugoslavia managed to reap geopolitical dividend by obtaining direct support, financially and in-kind, from the USA, and used indirect support (in fact, reaped an unexpected opportunity) which occurred due to simultaneous access to both Western and Warsaw Pact markets. This unique geopolitical position opened many opportunities for arbitrage, including arbitrages in technology which were copied from the West, produced locally and sold in the East and across the developing world. Shipbuilding, machine building and autoindustry emerged and developed based on this model. Many African and Asian countries also embraced socialism during decades of national liberation after the IIWW, lending more sympathies to "communist friends" than to companies and organisations from capitalist countries, which also imposed restrictions on international trade with socialist countries, or from Soviet command economy, which did not seem to be as attractive and successful (at least in their eyes) as Yugoslav model.

Yugoslavia's early divorce from the Soviet-type command economy led to the development of "market socialism". The system was based on vague concepts of enterprise selfmanagement and social ownership. In practice, this meant more freedom for craftsmen and private micro-enterprises (up to 10 employees) where ownership rights were defined in a similar way as in the capitalist countries. More importantly, market (self-management) socialism meant more freedom for the managerial elite in larger socially owned enterprises. Socialist managers could behave as de facto owners, ultimately imposing key statutory decisions, make contracts and set many prices freely, especially for consumer goods. They consolidated their interests and views as an autonomous elite and influential political group because top managers in large companies were also members of the communist party. They acquired public executive positions in the '70s and '80s as a generation of communists who were on the winning side in the IIWW gradually retired. Competition with East and West in terms of rates of economic growth was the main motive of the communistmanagerial elite in Yugoslavia, similar to awakened incentives among the communistentrepreneurial elite after Deng's reforms in China.

Still, ownership rights remained weekly protected. There were no capital markets. Rudimentary financial markets for money, foreign exchange, deposits and loans were segmented across borders of republics of former Yugoslavia and regions within the republics. Corruption was widespread, labour market segmented and inefficient as well. Capital controls were tough, and dual FX markets developed with the yawning spread between official and shadow exchange rate. Economic fundamentals were weak, and the economy could not survive the shocks of the 70's followed by political and inflationary 
shocks of the '80s. In addition, as USSR got weaker, Tito died (1980), and the US became more confident (during the second Reagan's term) that it will win the Cold War. Yugoslavia was losing international grounds. It wasn't an important element of Pax Americana any more.

In the late '80s, the socialist managers' elite was at the peak of its power. Last Yugoslav Prime Minister Ante Marković initiated a reform program on the grounds of killing high inflation, introducing liberalisation and privatisation. At that short time interval in history, it appeared to outside observers that Yugoslavia is the potential forerunner of market reforms in the socialist world. Marković had strong outside support from the US, European Community and international financial institutions. However, it was a brief historical moment without wider relevance. Reforms were only partially implemented and basically faded out into wars as the Yugoslav managerial, executive elite had no political power. They were not backed by the powerful military leaders who decided to support Serbian leadership. Also, the managerial elite had no legitimacy among the broader population in a country on the verge of dissolution (Bićanić \& Franičević, 2003).

Still, local memories about a quarter of the century from the early ' 50 s to late ' 70 s - a period when the country was transformed from largely backward rural European periphery to an industrial nation, especially in Slovenia and Croatia - remained embraced in schism similar to feelings after overeating with sugary products: something was wrong, fundamentally unhealthy, but in the short-term, it felt good, especially after use of brutal force to control society eased in the second half of the '50s. ${ }^{9}$ As a consequence, the post-1989 transformation in SEE was not rooted in clear ideas about socio-economic developments. The legacy of the last Yugoslav reform attempt in 1988-1989 headed by socialist managers' elite just faded into the footnote of books on economic history.

Key political personalities in the late '80s and early '90s focused on winning independence and war. Old managerial elites survived and tried to muddle through by using privatisation to cement their positions in the new states. Similar continuity was observed in the secret service: top agents quickly offered their services to new national elites who desperately needed their services during times of war. Survival and continuity of communist managerial and spy elite was representative of wider institutional continuity, which touched upon many walks of life, including social sciences in academia, media and culture. Only a few economists educated in the tradition of Western economics but limited in their true political influence held clearer views about causes of economic malaise and what ought to be done in order to promote economic transformation and modernisation.

As 90's passed by, full of "production of history" (as Churchill used to say about Balkans), SEE countries found themselves in de facto international isolation, deprived of deeper trade links with Europe (except Slovenia), and scarce of FDIs (except in banking and telecom industry where expected profits compensated for huge political risks). At the same time, Baltics and the CEE participated in the formation of new European economic geography after the fall of the Berlin Wall, preparing themselves for a big wave of eastern enlargement. Old trade and investment links with the West, primarily with Germany and Austria, were reestablished in Europe in the late 1990s and early 2000s. Trade and investment in Europe

9 Infamous communist concentration camp Goli Otok in northern Adriatic was closed in 1956 after it "hosted" around 16 thousand people. 413 were killed. Most prisoners were Stalin's supporters who opposed to Tito's breakup with Stalin in 1948, which led to opening of the camp in 1949. 


\section{DISCUSSION}

around the year 2000 were structurally more similar to Europe in 1930 than to Europe in 1989. SEE's fallout during the new dealing of historical cards was inevitable.

This conclusion should not be interpreted as a call for historical determinism in explaining transition in SEE. Still, historical determinism is not an idea that should be left behind easily. Historical thinking begs for an answer to the following question: what would have happened if EU integration in SEE was faster, i.e. what if there were no atrocities if former Yugoslavia could split in a peaceful way like Czechoslovakia, or at least in a less hostile way like the USSR in the early 1990s? Here, the historical determinism comes to the fore: I think SEE would undoubtedly have significantly higher living standards without post-Yugoslav wars, but it is hard to believe that results of relative economic development could have been much more different in this alternative history. The level of education of the general population and capacities for democratic and market reforms were lower in SEE compared to CEE and Baltics. This deficit would probably be present even in the case of the peaceful dissolution of the former federation.

Let us be clearer about the economic reform deficit in SEE. The reforms are like stones thrown by the sling. Reforms' ballistic path depends on the tension of the catapult. Ideas, beliefs and consistent plans determine direction and part of the tension. The rest of the catapult's tension depends on political skills: abilities to persuade, obtain broad support and break or avoid resistances to change. These factors depend on institutions, but institutions do not reflect currently dominant ideas; they arise from history, culture and widespread beliefs. Only when ideas, beliefs and plans meet political capacities for execution, reform stones thrown out of the sling can fly fast and far. Reforms also require inclusive institutions which facilitate sharing of reform benefits among the wider population in order to confirm major political narrative about promised future after reforms take place. Otherwise, reform outcomes are not sustainable. No such environment, a sling with a strong catapult which soon leads to a better life, existed in any country of former Yugoslavia around 1990.

Continuity and tradition of extractive institutions enabled narrow interest groups to capture benefits of change, which were rare anyway due to the direct impact of wars. As a consequence, corruptive practices continued under changed cloaks. Lack of trust became endemic in societies torn by wars. In the economic realm, it meant that competition in internal markets remained weak, regulatory burden high, administration slow, privatisation stopped before the large sector of state-owned enterprises was transformed, and capital markets remained shallow and of marginal importance for allocation of new capital. A new, hybrid post-socialist system was borne. Some authors (e.g. Bićanić \& Franičević, 2003) called it crony capitalism, but crony is an adjective that can serve equally well in different historical contexts. State capitalism is a better term because cronyism in SEE implies that state institutions could be captured from the very beginning of transition by strong companies. However, institutions were both strong and weak at the same time: they were strong due to their socialist legacy and brutal administrative power, which was executed in an arbitrary way ${ }^{10}$, and weak in their lack of transparency and control, which makes them

10 There was no tradition of challenging administrative and regulatory decisions in administrative courts which almost always confirmed administration's decisions. This problem persists to these days. World Economic Forum's Global 
especially prone to capture by the most powerful. But neither the most powerful nor most influential were businessmen. The political class ran the show. Hence state capitalism. ${ }^{11}$

Make no mistake: open political competition commenced in the '90s; there were elections which became fairer as time went by; no secret police could bump to your door in the night and take you to the investigation; people and media began to speak freely, criticising and attacking the incumbent government. There were both pluralisation and polarisation. Nevertheless, the level of centralisation and political control/influence remained similar to the decentralised socialist model of former Yugoslavia. A stone thrown from the sling during historical events of 1989-1991 did not fall far away.

Also, constitutions and ownership titles changed. Law-on-the-books became similar to Western role models. Basic corporate and banking laws were written with the assistance of western advisors according to the best practice. However, the effective structure of power remained in the hands of narrow national political elites, which continued to operationally decide on most aspects of life, including culture and the economy. In Baltics and the CEE, although corruption and elements of state capitalism persisted too, initial tension was stronger and energy for economic reform higher, so the reform stone could fly longer, further.

Despite overriding common factors at work in SEE, national specifics did matter a lot. Croatia managed to escape the slow convergence trap in the period of 1995-2008 due to pulling factors associated with ambition for (late) EU accession and early financial stabilisation, which led to strong capital inflows. However, after achieving EU membership in 2013 (the EU agreement was effectively signed in 2011), reform fatigue prevailed, and convergence became notoriously slow, coupled with mass emigration. Serbia and Bosnia and Herzegovina were slow to converge in all subperiods (similar to Albania), and Slovenia even diverged after the Great Recession, leaving the place on top of most developed CEE countries to Czechia in 2009 (according to Eurostat's purchasing power standard calculations). Montenegro managed to converge based on a low starting position and extremely strong capital inflows related to property business and tourism, a model neither achievable nor advisable for any other country. North Macedonia managed to converge also based on a low initial level of GDP per capita and business environment reforms that helped attraction of FDIs. Still, it lags behind significantly. When the level of convergence in SEE is looked at in conjunction with its long-term speed and volatility after three decades since the Berlin Wall had fallen, no SEE country came close to economic success stories in the Baltics ${ }^{12}$, Czechia, Slovakia, Romania and Poland.

Competitiveness Index displays value assessment for quality of challenge of administrative decisions, indicating Croatia significantly below CEE and Baltic countries in this respect.

11 In crony capitalism businessmen can become the most powerful. In state capitalism they cannot. Politicians and administration are always the most powerful as no private person can monitor or challenge their decisions.

12 We look at Baltic 3 as a homogenous group for convenience purposes. In fact, Latvia lags behind Estonia and Lithuania. 


\section{Fundamental reasons behind the choice of monetary and exchange rate regimes in SEE}

The main message of the sling effect is that a shared understanding of the root causes of economic problems and their solutions is a necessary condition for the sling effect of reforms to happen. In SEE, there was no such shared understanding about the role of open competition, an independent judiciary, efficient administration, deep capital markets, good government policies and well managed state-owned enterprises. Lack of accurate descriptions of the new hybrid system just added to the confusion: as the '90s came close to the end of the decade, academics, experts and politicians started to quarrel about too much or too little "neoliberalism" and Keynesianism and monetarism, as if any of these concepts meant anything in daily political debate. These were conceptual ghosts whose meaning was interpreted and abused according to current interests and illusions. Reality passed below these conceptual radars and continued to evolve in its own way, largely cementing the hybrid system, which was neither capitalism nor socialism, neither liberal democracy nor any known form of totalitarianism.

At first glance, it is a paradox that the monetary system, which is an effective tool for rent extraction (redistribution) was not used for this purpose by influential political interest groups which continued to keep tight control over potentially independent institutions and organisations. High inflation is a perfect example of an extractive mechanism that shifts the real value from the public at large (users of money services) towards privileged debtors who are in the front line to obtain credit or get a transfer. Also, at first glance, it is a paradox that key intermediaries in the system - banks - were privatised, in many cases to large European banking groups whose managers are harder to influence by local politicians due to rules of internal governance which are decisive for their careers. ${ }^{13}$ Banks could be a very attractive business for local political controllers if national ownership control was kept. But it wasn't. It is the sling effect that can help understand this paradox.

Recall that shared understanding of root causes of problems and their solutions is a necessary condition for the sling effect of reforms to happen. The high inflation process in the '80s and early '90s destroyed much real value and led to currency substitution widespread use of hard foreign currency (Anušić et al., 1995; Feige et al., 2002). Society at large understood how damaging the inflation process is. People expected and demanded the process to stop. During the war, until September 1993, Croatian National Bank accumulated enough international reserves to cover for the whole high-powered money M0. Its real value was depreciating rapidly, with the rates of inflation and currency depreciation approaching 40\% monthly in September 1993 on the eve of Croatia's stabilisation program. Technically, it meant that Croatia had resources to introduce a sustainable currency board as of 1993, in the midst of the war.

Hyperinflation was also out of control in Serbia, and Republika Srpska - part of Bosnia and Herzegovina controlled by the Serbs, later on, recognised as a constituent part of Bosnia

13 Slovenia is an exception. Largest banks remained government owned until Great Recession. As their nonperforming loans exploded after 2009, banks were resolved and privatised. It created political and judicial turmoil that lasts until today as there are many unfinished local and international lawsuits related to these events. 
and Herzegovina by the Dayton Agreement (a document that ended the war in $\mathrm{BiH}$ was signed in November 1995). With the maximum monthly rate of inflation at 313 million per cent, Serbian hyperinflation is considered to be among the five worst in history. Similar developments happened across former Yugoslavia, with many regional pockets like Kosovo effectively not using dinar but foreign currency. Locals share memories of monetary chaos, which is hard to be understood from the books; being one of the advisors to the Croatian government in the design of the 1993 stabilisation program, I vividly remember discussions about parallel currency - option to use Deutsch Mark as a legal tender in parallel with Croatian dinar (kuna currency was introduced later, in May 1994, after we were sure that high inflation is gone). This proposal never reached the president's desk.

Therefore, the strength of exchange rate regimes in SEE arose from weakness. The new political elite thought about the monetary system primarily as a potential source of wider credibility and support (subject to stabilisation) rather than as a source of quasi-fiscal financing of the government. There was a broad understanding that the monetary (inflation tax) base was not there anymore and that it has to be rebuilt by recovery of demand for domestic currency, which depends on expectations and credibility. In a similar vein, consent with bank privatisation was founded on the opportunistic calculation of costs and benefits by the new political elite. After they learned that value extraction and redistribution in a closed monetary and financial system leads to the collapse of the monetary base and capital flight, international financial integration and monetary stabilisation became attractive opportunities to ease access to capital and decrease its cost both for the public sector and for the public at large. What was good for the elite was good for most of the people. This fact explains why institutionally unfinished systems of SEE became attractive for foreign capital inflows before the Great Recession despite the lag in the EU accession process.

In terms of a historic institutional theory developed by North et al. (2009), inclusive institutions develop when the dominant coalition (elite) assesses the opportunity cost of running an extractive institution too high. Indeed, the potential benefits of opening, that is, turning monetary and financial institutions into the depersonalised, open-access format, increased with the building of potential access to sources of Western capital. Communists turned nationalists in SEE also recalled that it was access to Western credit that kept the ruined old system still running in the '70s and ' 80 s. By that time, they learned that they could not win the battle of financial capital in isolation. So, the fall of the Berlin Wall affected both sides of the elite's financial cost-benefit equation: speed up of inflation increased the cost of running extractive monetary institutions, while potential financial opening increased the expected benefits of the introduction of inclusive monetary and banking institutions, which limit inflationary taxation and attract capital inflows which brings much higher expected benefits than inflation of domestic monetary base. Unfortunately, no similar political cost-benefit calculation worked for other areas of economic policy.

Financial opening to international banks and capital proved to be a smart move. The period of excessive capital inflows before the Great Recession of 2008-2009 enabled rapid convergence everywhere, including the SEE. Recall Figure 1 and notice that Croatia is positioned next to CEE 4 in terms of total convergence mainly due to convergence in a few years prior to the Great Recession of 2008-2009. However, the logic of "too much of a good thing" (title of the IMF Working Paper by Duenwald et al. (2005) published in the midst of the capital inflows/credit boom in 2005) manifested through two channels. First, a waterfall 
of hard currency covered fundamental weaknesses and, as it landed on weak institutions, fertilised corruption. Second, as the tide turned to ebb with the emergence of the Great Recession, fuelless economies began to depend on weak fundamental factors of economic growth such as institutions, quality of policymaking and efficiency of (very large) public sectors.

On the waterfall of money and debt: the average current account deficit to GDP ratio in Croatia 2002-2009 was around $8 \%$ (a maximum of $10.5 \%$ was reached in 2008). Capital inflows were channelled by international banks, mainly by lending to households for house purchases (real estate prices were strongly appreciating) and to government and enterprises. Another key channel was the government sector: it worked mainly through state-owned enterprises, government bond issues and other forms of direct borrowing. Government channelled inflows mainly to construction projects such as highways and sports halls. These projects had very little impact on long-term productivity growth, similar to private sector real estate investments. So, instead of applying tight countercyclical policy (in order to correct for private sector excesses), the government could not resist the sweet call of easy money and added fuel on the fire. Such a story is nothing new under the sun. It was told in many countries at different points in history. However, when such a story is told as a boring narrative about macroeconomic imbalances, the reader misses the juicy details about the political economy which happened beneath the surface of financial flows. It would be a pity not to mention how inflated construction sector danced with government officials in order to fuel investment and corruption, how the general public warmly supported big construction programs of roads and sports halls with around $80 \%$ majority, how black channels for funding political parties found their ways like water through the stone, how public sector trade unions and government developed loving relations based on generous increases of wages in the public sector, and how Prime Minister at that time (2003-2009) Ivo Sanader resigned suddenly in the midst of 2009, just at the moment when the Great Recession hit the shore, fled the country after accusations for corruption, was captured in Austria, imprisoned, extradited back to Croatia, and how court cases against him are still pending as of today, leaving the public in doubt about the final verdict. How could it be that such an exciting sequence of events, rooted deeply in the history of weak democratic institutions, would have no long-run implications for economic growth many years after? This impact of long duration emerged not only because accumulated debts had to be repaid at higher interest rates in the period from 2009 to 2015, but more so because trust in institutions, if any existed prior to the events, was eroded to the minimum.

On the ebb phase: the benefit extraction phase ended with the emergence of the Great Recession. Figure 3 shows that growth in SEE slowed down significantly in the deleveraging period ${ }^{14}$, when the strength of capital inflows eased after 2009, except in

\footnotetext{
14 Deleveraging has many facets as it can be driven by both supply side and demand side forces. Extreme cases of private sector deleveraging (e.g. Latvia, Slovenia in Figure 3) were associated with banking crisis and massive cleaning of non-performing loans from banks' books after 2009. There were other one-off events in the last decade, such as forced write-offs of inflated principals of CHF loans (Croatia, Hungary, Poland). More gradual supply side and demand side adjustments are hidden below major one-offs. For example, banks in some countries were rebuilding their capital adequacy after the shocks of the Great Recession by very conservative lending practices, while deleveraging was demand-side driven in countries where banks did not have own capital problem. Slow economic growth and consumers' frustration after CHF loans appreciation episode were dominant explanation in Croatia. On the
} 
Montenegro and North Macedonia. On the other hand, rapid deleveraging in some countries of CEE and Baltics (effectively in all countries except Poland, Czechia and Slovakia) did not prevent them from keeping the pace of relative economic growth and convergence. Croatia firmly resides on the bottom of the list in this Figure.

Figure 3 | Average rate of growth and change in private sector credit to GDP ratio 2010-2019

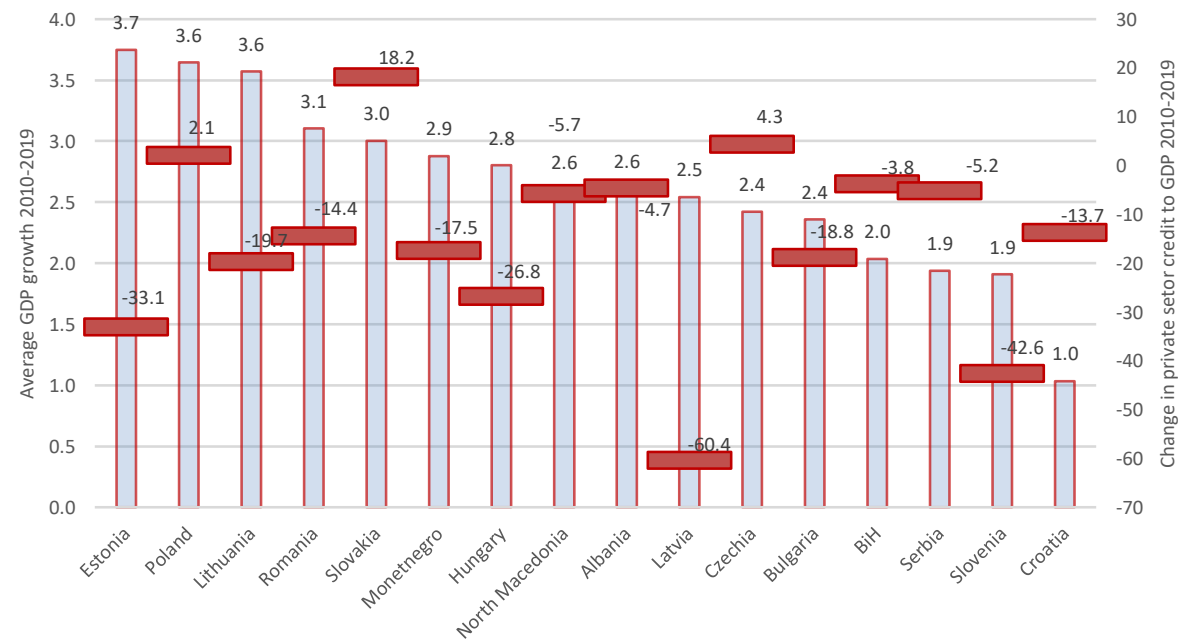

口Average GDP growth 2010-2019 - Change in private sector credit to GDP 2010-2019

Methodological note: arithmetic average for rates of growth; change in private sector credit to GDP ratio in percentage point calculated from WDI's series "Domestic credit to the private sector (\% of GDP)".

Source: World Development Indicators, own calculations.

In conclusion, when the wave of strong, excessive capital inflows ended in the outburst of the Great Recession in 2008 and 2009, domestic demand was everywhere brought in line with aggregate supply. The current account deficit turned into a current account surplus since 2014 in Croatia. Economic growth became more dependent on fundamental sources of growth: strength of institutions, the efficiency of administration and public sector in general, competitiveness, capacity for innovation, entrepreneurial dynamics, quality of education and match of education outcomes with labour market demand. EU funds also helped countries that had access. SEE's a significant lag in these areas came to the surface, presenting its limits to economic growth until today.

\section{Concluding remarks: loose slings are the future?}

Convergence in Croatia and the SEE (with a notable exception of Romania) was slower than expected and concentrated in the period before the Great Recession (especially in 2001-2008). However, post-Great Recession convergence was very slow in Croatia,

other hand, deleveraging did not occur in a few countries which managed to grow at a relatively solid pace in the last decade (Poland, Czechia and Slovakia). 


\section{DISCUSSION}

Serbia, BiH and Slovenia. Post-Yugoslav wars directly explain slow convergence or its absence before 2000, but indirect effects of wars and other factors explain slow convergence after the Great Recession. The sling effect of reforms - lack of common understanding of causes and potential solutions for economic malaise - explain part of the differential development path, as successful institutional and economic reforms in Baltics and CEE happened out of initial energy that emerged from a shared understanding of root causes of socio-economic problems and their solutions. The ambience was different in SEE. There was only one economic problem that met the tense sling criterion - high inflation. Preference for stable exchange rate regimes can be explained by a widely shared understanding of the social cost of high inflation and the potential benefits of remedies produced by credible exchange rate pegs. It also helped capital inflows before the Great Recession, when all SEE countries converged successfully as well. However, when the era of financial excesses ended in 2009, growth slowed down. It slowed down not only in absolute terms (this happened everywhere in the post-communist world) but also in relative terms. Weak institutions and inefficient public sectors persisted, recovery from the Great Depression was slow, and economies could not grow fast enough without the fuel of some kind of permanent deficit which structurally shifts aggregate demand significantly above the aggregate supply for a longer period of time.

Croatia found a middle ground in terms of institutional development as (late) EU accession provided a motive for some reforms. But that was sufficient for the wave of convergence until 2009 only. The level of institutional development remained weaker compared to CEE 5 and Baltic 3 for most of the post-socialist period.

Croatia still has a potential for faster catch-up because years of intense use of EU funds are ahead. ${ }^{15}$ The likely introduction of Euro several years ahead (recall that Croatia is a member of ERM II since July 2020) will be the logical conclusion of recent monetary history. Euro introduction has some potential to facilitate growth due to savings of transaction costs, lower interest rates, elimination of currency risk and greater efficiency of countercyclical monetary policy. But these effects are expectedly small compared to growth anchors that are reflected in fundamental weaknesses. Further institutional advancement and convergence are far from certain because Croatia lacks internal incentives for reform. After all, Slovenia's divergence during the last decade is a witness to the weak potential of solid monetary arrangements to substitute for fundamental reforms.

Perspectives for the rest of the SEE are bleak as long as they remain in a limbo vis a vis EU accession and do not find internal motives for change. Serbia, Bosnia and Herzegovina and North Macedonia may find pockets of opportunity for the exports sector based on the attraction of FDIs due to competitive unit cost of labour and tax incentives schemes, similar to models used in Slovakia 20 years ago and Romania 10-15 years ago. However, development models based on FDI-exports nexus cannot sustain long-term convergence if economic growth is not supplemented by institutional reforms. And if there are no spillovers of benefits to other sectors and the wider population. Serbia's success with exports and failure in terms of convergence after the Great Recession is an illustrative point.

15 In the next 10 years Croatia has an opportunity to use EU funds in proportion to $50 \%$ of 2019 GDP i.e. 5\% of GDP per annum on average. 
Inclusive institutions are needed for spill-overs to happen, and history teaches that their development is slow in this region.

Broader reflection on SEE's developmental problem leads to the following question: is SEE (notably countries which gained independence after the break-up of former Yugoslavia in 1990-1991) really so specific? CEE 5 made most of its institutional improvements between 1990 and 1995 when the sling was under strong tension. As years went by and the fall of the Berlin Wall was fading out to the distant past, institutional reforms stopped and reversed. This problem does not boil down to the new political strategies of Orban/Fidesz in Hungary and Kaczynski/PiS in Poland. Hungary and Poland are widely covered in European media and researched by scholars because of their attempts to control the judiciary, media and civil society. Such political efforts visibly depart from European standards of liberal democracy. More importantly, it means that the EU consensus-style of decision making gives voting powers to officials elected in countries with weak democratic institutions. ${ }^{16}$ However, institutional fatigue is not a new phenomenon restricted to Hungary after 2010 and Poland after 2015. Measures of institutional quality show that malaise is there for a long time, with a notable exception of Baltic countries. The crucial question is whether the catch-up process can continue without advancement in the area of institutional reforms?

For the time being, CEE institutional malaise was not transmitted onto slower convergence except in the case of Slovenia, where state-owned banks' lending to rapidly growing construction tycoons during the period of financial excess led to massive bank failure and long political frustration. As causality between institutional development and economic growth is far from clear (and blurred by the time lag), the lesson to be learnt is that economies can grow relatively rapidly even when institutions stagnate or regress. This finding is well known for countries at relatively low levels of income (e.g. China). Recent experience in CEE shows that the same is possible at medium and high levels of economic development (this sentence should not be interpreted as a statement that the level of democratic development in CEE and SEE is comparable to China, it is far higher). Economic openness and skilful macroeconomic management can substitute for institutional advancement as long as authorities do not interfere with the functioning of markets and provide a reasonably favourable business environment and fundamentals for company growth.

This fact is nothing new under the sun. In our choice of institutional indicators that were presented in Figure 2 we favoured those which closely reflect democratic developments (voice and accountability; the rule of law; control of corruption). The other trio of Worldwide Governance Indicators (regulatory quality, government effectiveness, political stability and absence of violence) is more closely related to general public sector efficiency than to democratic developments. This distinction between two groups of institutions is important because weak democracies can have a high quality of regulation, effective government, low violence and political stability. Some of these factors were emphasised by Fukuyama (2015), who defined effective state power based on professional bureaucracy (meritocracy) as a necessary condition for political order and development. There are such places in the world, like Singapore, where democracy rankings are low and effectiveness rankings are

${ }^{16}$ Recent political clash over implementation of the rule of law criterion in allocation of extended EU funds via Next Generation EU program between Hungary and Poland on one side and old EU on the other is illustrative. 
high, showing that a small economy can prosper in an effective political environment without too much democracy as long as it remains competitive and open.

This worldview is present in statements by some of the prominent figures from the new generation of leaders in CEE who deliberately chose to prefer goals of international competitiveness and efficiency over the development of democracy (Orban, 2014). ${ }^{17}$ It remains to be seen for how long the two institutional paths may diverge (democratic development versus effective political order) if a country wants to develop further in a highincome segment. Asian experience shows that there is no contradiction between the two.

But that is Asia, and this is Europe. A lot will depend on wider European developments because former communist countries are too small to develop internal economic dynamics on their own. Baltics, CEE and SEE need open and growing Europe to develop further. If European economic malaise persists, different historical trajectories may emerge. Turning to Asia (China) is an option, although Chinese attempts for soft penetration to Central Europe (including Chinese investments in Italy) ${ }^{18}$ did not go too far. However, recent issues of panda government bonds by Hungary and Poland in China do represent an important signal. Turning to Russia is not an option despite energy ties for reasons of historical frustration and Russia's economic weakness. But different paths are possible in the future if Russia finds a way to grow faster and import significantly more goods and services from the West, simultaneously finding the way to communicate better with former Warsaw Pact countries without instilling memories from the Soviet past. Turning more to the USA is always an option.

Despite different possibilities for turns in the inherently unpredictable globalisation process, the EU is the home base for former communist countries. EU is a historic anchor which, after all, played a critical role in the fall of the Berlin Wall and in the post-communist transformation next to the US. This job is still largely unfinished in SEE, where the economic future depends primarily on the pace of local European integration, which is coming two decades too late, with both sides sharing the responsibilities for a long delay. Uncertainties related to desires and capacities for further enlargement in the post-Brexit EU represent a new risk factor for part of the SEE, which is still outside the EU.

In a broader picture, laggards in SEE are special cases. The historical fate of these countries depends exclusively on the EU's ability to reinvent itself after three consecutive shocks in a relatively short period of time: Great Recession, Brexit and COVID-19. EU's

\footnotetext{
17 In his speech to Hungarian minority in Romania in Baile Tusnad in July 2014 Viktor Orban declared that the World is going through "regime change" due to emergence of new historic reference points. The fall of the Berlin Wall is not a valid reference point any more, as new generations of voters have different experiences primarily coloured by "Western financial crisis". He confronted Western ideas from pre-2008 dominant liberal world view (which are allegedly coloured by corruption, sex and violence) to Eastern traditional ideas which have to be shaped in a way which will ensure international competitiveness. Here comes the critical part of Orban's speech: "... the defining aspect of today's world can be articulated as a race to figure out a way of organising communities, a state that is most capable of making nations competitive. This is why... a trending topic in thinking is understanding systems that are not Western, not liberal, not liberal democracies, maybe even not democracies, and yet making nations successful." So, according to Orban, the West needs to turn liberal democracies into illiberal ones within the concept of the "workfare state". This state will prevent abstract liberal dogmas of freedom and fairness to secure dominance of the strong over the weak. Here the speech drifts into the mish-mash of loosely articulated philosophical and historical considerations with the only concrete economic point being focused on expanding state-owned property.

18 In 2019 Italy became the first G-7 country to join the Chinese Belt and Road Initiative.
} 
ability for finding responses to new challenges, such as the Next Generation EU programme, is encouraging. However, as new layers of more recent history cover more distant events which happened around the time of the fall of the Berlin Wall, it appears that something is different nowadays. New history in the making rests upon pragmatism and cold opportunity calculations which are different from old history-making, which was firmly rooted in the ideology of freedom and democracy. Therefore, the reform sling is loose now; new tensions can emerge in a number of different, unpredictable ways. But whatever the direction they take, it does not mean that future events will have nothing to do with history, which happened three decades ago. Different paths of Baltic 3, CEE 4, and SEE witness that geography and history matter, at least to some extent. It will, most probably, continue to matter in the future because collective memory, values and habits rest with institutions. They are like long neurons which transmit past to the future. Sometimes in happy, and sometimes in unhappy ways.

\section{References}

Acemoglu, D., Johnson, S., \& Robinson, J. (2005). Institutions as a Fundamental Cause of Long-Run Growth. In: Aghion, P., \& Durlauf, S. (eds.). Handbook of Economic Growth, Volume 1A, Elsevier, 385-472.

Anušić, Z., Rohatinski, Ž., \& Šonje, V. (1995). A Road to Low Inflation: Croatia 1993-1994. The Government of the Republic of Croatia, Zagreb.

Bićanić, I., \& Franičević, V. (2003). Understanding Reform: Case of Croatia. The WIIW Working Papers 033.

Bićanić, I., Deskar-Škrbić, M., \& Zrnc, J. (2016). A Narrative Explanation of Breakpoints and Convergence Patterns in Yugoslavia and its Successor States 1952-2015. WIIW Balkan Observatory Working Papers 122.

Duenwald, C., Georguiev, N., \& Shaechter, A. (2005). Too Much of a Good Thing? Credit Booms in Transition Economies: the case of Bulgaria, Romania and Ukraine. IMF Working Paper 05/128.

Eurostat (accessed December 28th 2020).

Feige, E., Faulend, M., Šonje, V. \& Šošić, V. (2002). Curency Substitution, Unofficial Dollarisation and Estimates of Foreign Currency Held Abroad: The Case of Croatia. In Blejer, M. \& Skreb, M. (eds): Financial Policies in Emerging Markets. Chicago: MIT Press.

Fukuyama. (2015). Political Order and Political Decay: From the Industrial Revolution to the Globalisation of Democracy. New York: Farrar, Strauss and Giroux.

Glaeser, E., La Porta, R., Lopez-de-Silanes, F., \& Shleifer, A. (2004). Do Institutions Cause Growth? NBER Working Paper Series 10568.

Keane, J. (2020). The New Despotism. Cambridge, Mass.: Harvard University Press.

Leblang, D. (1999). Domestic Political Institutions and Exchange Rate Commitments in the Developing World. International Studies Quarterly, 43(4), 599-620.

North, D., Wallis, J., \& Weingast, B. (2009). Violence and Social Order: A Conceptual Framework for Interpreting Recorded Human History. Cambridge: Cambridge University Press.

Orban, V. (2014). Full text of Viktor Orban's speech at Baile Tusnad (Tusnadfuerdo) of 26 July 2014. https://budapestbeacon.com/full-text-of-viktor-orbans-speech-at-baile-tusnad-tusnadfurdo-of26-july-2014/ 


\section{DISCUSSION}

The World Bank, World Development Indicators (accessed December 28th 2020).

The World Bank, Worldwide Governance Indicators (accessed December 28th 2020).

The discussion paper passed the review process. | Received: February 23, 2021; Revised: May 5, 2021; Accepted: May 27, 2021; Published: June 1, 2021. 


\section{Appendix}

Table A1 | GDP per capita at purchasing power parity in \% of level for Austria

\begin{tabular}{|c|c|c|c|c|c|c|c|c|}
\hline Region & 1952 & 1973 & 1980 & 1990 & 1995 & 2000 & 2008 & 2019 \\
\hline Baltic 3 & n.a. & $71.5 \%$ & $63.1 \%$ & $58.0 \%$ & $25.1 \%$ & $29.4 \%$ & $50.9 \%$ & $62.3 \%$ \\
\hline CEE 4 & $61.4 \%$ & $51.4 \%$ & $46.8 \%$ & $38.7 \%$ & $41.7 \%$ & $42.6 \%$ & $54.7 \%$ & $61.1 \%$ \\
\hline Slovenia & $62.2 \%$ & $83.1 \%$ & $96.4 \%$ & $67.2 \%$ & $57.5 \%$ & $61.3 \%$ & $71.6 \%$ & $70.3 \%$ \\
\hline Croatia & $43.3 \%$ & $55.7 \%$ & $64.7 \%$ & $48.1 \%$ & $33.8 \%$ & $37.5 \%$ & $50.3 \%$ & $51.6 \%$ \\
\hline Bulgaria & $47.7 \%$ & $47.0 \%$ & $43.9 \%$ & $33.1 \%$ & $32.7 \%$ & $21.9 \%$ & $34.1 \%$ & $41.9 \%$ \\
\hline Romania & $16.3 \%$ & $24.1 \%$ & $25.0 \%$ & $20.8 \%$ & $22.9 \%$ & $19.9 \%$ & $40.7 \%$ & $55.1 \%$ \\
\hline Montenegro & $28.2 \%$ & $28.7 \%$ & $36.4 \%$ & $24.5 \%$ & $12.1 \%$ & $17.4 \%$ & $33.4 \%$ & $39.8 \%$ \\
\hline North Macedonia & $34.0 \%$ & $41.7 \%$ & $45.1 \%$ & $34.1 \%$ & $23.8 \%$ & $20.9 \%$ & $25.5 \%$ & $39.6 \%$ \\
\hline Albania & $26.4 \%$ & $20.2 \%$ & $17.1 \%$ & $14.8 \%$ & $12.4 \%$ & $13.2 \%$ & $19.9 \%$ & $24.3 \%$ \\
\hline Serbia & $32.1 \%$ & $43.1 \%$ & $48.9 \%$ & $36.2 \%$ & $18.0 \%$ & $20.5 \%$ & $30.6 \%$ & $32.3 \%$ \\
\hline Turkey & $39.9 \%$ & $28.2 \%$ & $27.7 \%$ & $32.2 \%$ & $33.6 \%$ & $32.3 \%$ & $38.8 \%$ & $47.1 \%$ \\
\hline $\mathrm{BiH}$ & $30.0 \%$ & $26.8 \%$ & $30.0 \%$ & $21.9 \%$ & $10.9 \%$ & $20.4 \%$ & $22.5 \%$ & $24.3 \%$ \\
\hline
\end{tabular}

Methodological note: Time series for individual countries are not directly comparable as for all countries except $\mathrm{BiH}$ data from two different sources are combined. For EU member states, Maddison Project Database (ver. 2020) is used for 1952, 1973, 1980 and 1990. Eurostat is used from 1995 onwards. For non-EU member states, Maddison Project Database is used for 1995 as well, except for $\mathrm{BiH}$, which reflects Maddison Project Data for the whole period and column 2019 displays the last data (for 2018) in this data source. The same applies to Montenegro, which reflects Eurostat data for 2008 and 2019 only. Aggregates for Baltic 3 and CEE 4 are calculated as simple averages.

Source: Eurostat and Maddison Project Database, version 2020. Bolt, Jutta and Jan Luiten van Zanden (2020), "Maddison style estimates of the evolution of the world economy. A new 2020 update". 
Table A2 | Key indicators of institutional development in Central and South-East Europe

\begin{tabular}{|c|c|c|c|c|c|c|c|c|c|}
\hline \multirow[t]{2}{*}{ REGION } & \multicolumn{3}{|c|}{$\begin{array}{c}\text { VOICE AND } \\
\text { ACCOUNTABILITY }\end{array}$} & \multicolumn{3}{|c|}{ RULE OF LAW } & \multicolumn{3}{|c|}{$\begin{array}{l}\text { CONTROL OF } \\
\text { CORRUPTION }\end{array}$} \\
\hline & 1996 & 2008 & 2019 & 1996 & 2008 & 2019 & 1996 & 2008 & 2019 \\
\hline Albania & -0.65 & 0.17 & 0.15 & -0.68 & -0.59 & -0.41 & -0.89 & -0.59 & -0.53 \\
\hline Austria & 1.45 & 1.36 & 1.33 & 1.81 & 1.92 & 1.88 & 1.73 & 1.84 & 1.55 \\
\hline Bulgaria & 0.43 & 0.58 & 0.38 & -0.34 & -0.11 & 0.04 & -0.36 & -0.25 & -0.16 \\
\hline $\begin{array}{l}\text { Bosnia and } \\
\text { Herzegovina }\end{array}$ & -0.10 & 0.02 & -0.20 & -0.24 & -0.41 & -0.23 & -0.27 & -0.36 & -0.61 \\
\hline Czech Republic & 1.03 & 1.03 & 0.94 & 0.92 & 0.91 & 1.05 & 0.68 & 0.36 & 0.51 \\
\hline Estonia & 0.93 & 1.09 & 1.21 & 0.57 & 1.20 & 1.28 & 0.45 & 0.99 & 1.54 \\
\hline Croatia & -0.16 & 0.47 & 0.53 & -0.63 & 0.09 & 0.37 & -0.58 & -0.01 & 0.13 \\
\hline Hungary & 1.02 & 0.97 & 0.22 & 0.91 & 0.93 & 0.49 & 0.67 & 0.47 & 0.00 \\
\hline Lithuania & 0.98 & 0.85 & 1.02 & 0.45 & 0.72 & 1.02 & 0.42 & 0.14 & 0.68 \\
\hline Latvia & 0.72 & 0.78 & 0.88 & 0.13 & 0.81 & 1.01 & -0.20 & 0.25 & 0.48 \\
\hline Kosovo & n.a. & -0.31 & -0.13 & n.a. & -0.59 & -0.39 & n.a. & -0.63 & -0.56 \\
\hline North Macedonia & -0.39 & 0.20 & 0.00 & -0.31 & -0.35 & -0.24 & -0.61 & -0.19 & -0.41 \\
\hline Montenegro & n.a. & 0.24 & 0.03 & n.a. & -0.08 & 0.10 & n.a. & -0.21 & -0.03 \\
\hline Poland & 1.04 & 0.95 & 0.70 & 0.77 & 0.55 & 0.45 & 0.71 & 0.46 & 0.60 \\
\hline Romania & 0.29 & 0.51 & 0.49 & -0.02 & -0.01 & 0.36 & -0.45 & -0.14 & -0.13 \\
\hline Slovak Republic & 0.64 & 0.94 & 0.91 & 0.16 & 0.59 & 0.56 & 0.22 & 0.36 & 0.33 \\
\hline Slovenia & 1.28 & 1.02 & 1.01 & 1.07 & 1.01 & 1.12 & 1.11 & 0.98 & 0.91 \\
\hline Serbia & -1.22 & 0.28 & 0.03 & -1.26 & -0.50 & -0.12 & -1.14 & -0.31 & -0.45 \\
\hline Turkey & -0.13 & -0.04 & -0.81 & -0.14 & 0.08 & -0.28 & -0.15 & 0.11 & -0.29 \\
\hline
\end{tabular}

Methodological note: Values of indicators are placed within the interval from approximately -2.5 to 2.5 according to the methodology of unobservable components. -2.5 is related to the worst and 2.5 to the best outcomes. Voice and Accountability capture perceptions of the extent to which a country's citizens are able to participate in selecting their government, as well as freedom of expression, freedom of association, and free media. The rule of law captures perceptions of the extent to which agents have confidence in and abide by the rules of society, and in particular the quality of contract enforcement, property rights, the police, and the courts, as well as the likelihood of crime and violence. Control of corruption captures perceptions of the extent to which public power is exercised for private gain, including both petty and grand forms of corruption, as well as "capture" of the state by elites and private interests.

Source: Worldwide Governance Indicators 